FACTA UNIVERSITATIS

Series: Economics and Organization Vol. 16, N $\mathrm{N}^{\mathrm{o}} 3,2019$, pp. 269 - 282

https://doi.org/10.22190/FUEO1903269J

Original Scientific Paper

\title{
RELATIONSHIP BETWEEN EASE OF DOING BUSINESS INDICATORS AND THE FOREIGN DIRECT INVESTMENT INFLOWS IN THE REPUBLIC OF SERBIA
}

\author{
UDC 339.727.22(497.11)
}

\author{
Marko Janaćković ${ }^{1 *}$, Marija Petrović-Ranđelović \\ ${ }^{1}$ Higher Business School of Professional Studies, Leskovac, Serbia \\ ${ }^{2}$ University of Niš, Faculty of Economics, Serbia
}

\begin{abstract}
The importance of Ease of Doing Business indicators as determinants of FDI inflows has attracted attention in establishing their connections. The aim of the research is to examine the relationship between the Ease of Doing Business indicators and foreign direct investment (FDI) inflows. Dynamic and correlation analysis are applied in the consideration of the interdependence of Doing Business indicators, Starting Business, Construction Permits, Getting Electricity, Registering Property, Getting credit, Paying taxes, Trading across borders, Enforcing contracts, and Resolving insolvency, with FDI inflows. The obtained results show that Resolving insolvency and Construction Permits have the highest degree of agreement with FDI, while the negative agreement with FDI trends is shown by Getting Electricity, Registering Property, Getting Credit, and Enforcing contracts. The main results of this research are useful for economic policy makers because they provide a good basis for formulating the strategy of improving the business environment in the Republic of Serbia.
\end{abstract}

Key words: FDI inflows, Doing Business indicators, Republic of Serbia

JEL Classification: F21, F23

\footnotetext{
Received March 11, 2019 / Revised April 19, 2019 / Accepted May 17, 2019

* PhD student at University of Niš, Faculty of Economics, Serbia

Corresponding author: Marija Petrović-Ranđelović

University of Niš, Faculty of Economics, Trg kralja Aleksandra Ujedinitelja 11, 18000 Niš, Serbia

E-mail: mrjpetrovic76@gmail.com

() 2019 by University of Niš, Serbia | Creative Commons Licence: CC BY-NC-ND
} 


\section{INTRODUCTION}

Foreign Direct Investment (FDI) is widely considered in numerous surveys from different perspectives. In general, if countries are at a similar level of economic development, those who attract more FDI are considered more competitive. Considering the growing importance of FDI for the economies of countries, the importance of analyzing the costs and benefits of such investment is emphasized. In this way, multinational companies not only maximize benefits, but can also minimize their costs. Higher economic growth based on FDI is achieved through numerous benefits at different levels. FDI benefits are associated with technology transfer, better use of available resources, and the introduction of new processes, international trade integration, and plant development. Given that FDI is identified as positive for the country's development, it is important to explore the characteristics and policies of countries to attract FDI. With policies attracting FDI inflows, the host country can improve the business environment. Leaders require trade promotion, and creation of a long-term relationship that will distinguish FDI from one-time import-export contracts. In order to promote confidence in the market, it is proposed that governments define business rules, ensure presence and demonstrate loyalty to the private sector. Governments strive to improve policies, conditions and legislation, and introduce laws to create a simple and secure environment for business and attract FDI. These improvements are measured by the Doing Business indicators of the World Bank. Doing business is an annual survey, including a large number of "Ease of Doing Business" indicators, to assess and rank countries based on their quality to attract FDI. Therefore, ease of doing business represents an economic ranking based on the assessment of the ease of doing business in a particular economy. The higher ranking indicates that the regulatory environment is more suitable for the start-up and the functioning of a local company. Better economic governance (banking and finance, fiscal burden, monetary policy), less government participation in the economy, less government intervention, higher levels of political freedom, and the absence of wage and price controls contribute to higher FDI inflows.

The first part of the paper provides a literature overview of the World Bank's Doing Business indicators. The second part is devoted to the connections of Doing Business indicators with FDI inflows, while the third part presents methodology of the research and hypotheses. The fourth part gives the results of the research.

\section{EASE OF DOING BUSINESS}

Since 2006, the World Bank has adopted an approach to rank nearly 200 countries based on their business environment and "ease of doing business" in these economies. The essence of the approach is reflected in the importance of the prosperity of the private sector in the promotion of growth and development. In general, the main idea is that simpler business start-up encourages an increase in the number of investors, which affects the increase in the number of jobs. The World Bank's analysis points to the link between a good business environment and promotion of competitiveness, innovation and expansion (World Bank, 2013). The business environment is also linked to the institutional environment in the country. If the country has strong institutions, it becomes more attractive for foreign direct investment, bearing in mind that the cost of transactions is reduced by increasing the efficiency of the host country market. 
The World Bank's Doing Business report is based on certain criteria for evaluation and ranking of business simplicity. Doing Business indexes analyse areas, which are made up of several indicators (variables) representing qualitative measures. Indices are divided into following areas: starting a business, working with building permits, registering ownership, obtaining a loan, investor protection level, paying taxes, cross-border trade, respecting contracts, closing a business (or resolving insolvency), hiring workers, and obtaining electricity. They do not include certain business norms such as: macroeconomic stability, corruption, working skills of the population, security level, specific legislation for foreign investment, or infrastructure quality. In the further text it is shown how Doing Business in general, and above-mentioned criteria individually, are related to growth and development indicators.

Starting a business. The decision of an investor regarding whether to start a particular business is determined significantly by the simplicity of starting a business. A large number of empirical research studies highlight and confirm that entry barriers prevent development, while empowering forms that would lose part of the market share if someone applies more efficient technology (North \& Thomas, 1973). Higher initial costs are a barrier to creating an enterprise, and higher costs of starting up operations affect an entrepreneur's withdrawal from creating a company. In this case, they become employees, not employers, which affects the reduced number of potential jobs. The entry barriers discourage companies from entering, which is primarily the case with small businesses (Klapper et al., 2006). Numerous procedures for starting a business, as well as higher start-up capital, reduce the scope of business activities. Higher capital affects the reduction in the level of entrepreneurship, and shorter time to register a company affects the increase in the number of enterprises in those industries with rising demands on the world markets. Reduced costs, shorter time and simplification of procedures in starting up operations affect the increase in the number of registered companies.

In a number of studies, the connection of entry barriers for businesses and determinants of growth is emphasized. A link between lower entry barriers and precise regulation and improvement of productivity factors was established. It was concluded that several entry barriers affect the lower overall productivity factor (Moscoso, Boedo \& Mukoyama, 2012). A negative link between input costs and productivity factors is identified, and that easy entry allows adaptation and faster spread of the best technology, leading to a faster growth of productivity factors.

Getting a loan. The influence of finance is significant for growth and development (Schumpeter, 1912). On the other hand, certain authors point out that financial development is not significant for growth (Lucas, 1988). Based on a survey conducted by King \& Levine (1993), it is concluded that there is a positive link between financial development and GDP growth per capita and capital accumulation. In addition, it is emphasized that there is a need to have programs that will allow better access to loans for enterprises, that is, the availability of loans not necessarily follows the increase in economic activity. Financial development positively influences growth by providing businesses with easier access to credit. In addition, credit-worthy companies grow faster in financially more developed countries. Financial development positively influences growth by reducing credit constraints, while it is noticed that financial development manages credit constraints to a significantly greater extent for smaller companies.

Implementation of contracts and good institutions. In order to simplify business, growth and development, it is necessary to establish efficient mechanisms for implementation of 
contracts and good institutions. This facilitates access to credit, improves trade and reduces the informal sector (World Bank, 2013). Particular attention is paid to the importance of institutions and management to growth and development, in terms of the importance of good institutions for promoting economic growth (Djankov et al., 2003). Three foundations of efficient market created by good institutions are: protection of property rights, implementation of contracts and collective action (Dixit, 2009). Through the protection of property rights, investments are made by individuals, who will later collect the fruits of their investments. Implementation of contracts is aimed at individuals participating in mutual benefit transactions. Institutions with better enforcement mechanisms prevent one party from doing fraud transactions causing losses to the other party.

Certain research indicates how implementation or compliance with the contract affects the development and simplicity of business (Dixit, 2009). The model suggests that in countries that have problems in implementing contracts, investors and contracting parties are in the "prisoner's dilemma" situation. High costs of implementing a contract may affect one party's failure to fulfil its obligations, which adds additional caution to investors when defining projects. In addition to this, an additional model emphasizing that problems of contract realizations cause higher macroeconomic volatility is created.

Developed legal institutions simplify the growth of enterprises by allowing them to gain simpler access to long-term financing. The countries with effective implementation of contracts have developed banks, and weak implementation of the law relates to a smaller financial market. The quality of institutions is the most important determinant of access to loans at the country level.

Effective compliance with contracts and good institutions also improves a trade. Effective compliance with contracts promotes comparative advantages in terms of goods for which production contractual relationships with third parties are necessary. Limited compliance with contracts and weak institutions are associated with the size of "grey" economies and foreign direct investment. The survey was conducted on the basis of data from 4000 companies from 40 countries, showing that a higher level of legal system reduces the size of the informal sector (Dabla-Norris et al., 2008). Quintin (2008) defines the model describing how to reduce the size of the informal economy by improving compliance with contractual obligations on formal funding. In addition, the rule of law significantly increases the level of foreign direct investment, i.e. countries where the ways of registering assets are simpler are more attractive to FDI.

Investor protection. The issue of investor protection is significant for minority owners of a company. If an investor protection is weak, investors will not invest in a corporation unless they are the majority owners. In this way, the market is prevented from financing the growth of enterprises (World Bank, 2013). In general, investor protection promotes economic growth and risk taking with regard to large investments. Better investor protection positively impacts companies in terms of risk taking and positively affects growth. Investor protection can also affect growth through financial markets, where poor investor protection is associated with the smaller financial market. Poor investor protection can lead to higher costs of external financing. Like investor protection, ownership protection, also encourages investments. When ownership protection is secured, investors are convinced to benefit from their investments. A positive link exists between the quality of institutions, such as the ownership protection (property rights) and investment, and growth. The existence of a positive link between the quality of property rights and the reinvestment of a company's profit initiates a positive link between property rights and growth. 
Property rights promote economic growth through better allocation of resources. The impact of property rights on growth is generally viewed as providing an initiative for investors to invest. Besley \& Ghatak (2009) identified four channels in which the property rights affect economic activity and growth, which include: 1) minimizing the risk of expropriation, 2) reducing the costs of protection, 3) property rights in the realization of trade gains, and 4) support of property rights to other transactions, and in particular regarding the loan claiming the guarantee.

The link between property rights and growth is complex, which points out the analysis of data panels from 91 countries in the period from 1980 to 2005 (Bose et al., 2012). There is a positive link between property rights and growth in the countries in which financial institutions are developed, while in the developing countries there is an optimal level of property rights. Below and above this basic level lower growth will be achieved. On the other hand, the bidirectional causality between property rights and growth is identified, in the sense that ownership of land is the basis for the development of large enterprises, while the growth of companies improves property rights. Strong property rights have a positive effect on wealth and capital formation, that is, property rights positively affect investment and growth.

Paying taxes. Based on the analysis of the World Bank, it was found that the tax administration is one of the first 11 business constraints, while taxes are among the top 5 basic business constraints (World Bank, 2013). Research focuses on the relationship between tax rates and development indicators. The conclusion was made that high tax rates adversely affect total investments, reduce FDI, reduce entrepreneurial activity and increase the informal sector. Higher tax rates may be associated with lower growth, and there is a negative link between tax rates and tax evasion. The Tax Administration is also an important aspect of taxation for ease of doing business and its impact on growth and development. Bird (1989) points out that tax administration should have the same or even greater significance than the tax structure of the tax system reform. The tax system of a particular country should be such that it works effectively and efficiently surrounded by the institutional weaknesses of a country.

Cross-border trade. The trade aims to allow manufacturers to expand their product market and to purchase inputs at the best prices. This is impossible to achieve if business is done exclusively on the domestic market. Certain studies have shown that in some African countries, due to inefficient trading procedures, revenue losses are almost 5\% of GDP (World Bank, 2013). Trading costs are higher in developing countries. Inefficiency in trade, especially in developing countries, imposes reforms in certain areas. Developed countries and developing countries differ in terms of the necessary reforms. The richer countries have to implement information and communication technology reforms, while developing countries need infrastructure and regulatory reforms. Simpler movement of goods through better infrastructure and institutions will have the greatest effects on improving trade for developing countries. Trade performance is most affected by the availability of information regarding trade, simplification and harmonization of documents, simplification of procedures and automation of processes.

Other indicators. In addition to the specific components, Ease of Doing Business is analysed also, in general, and its relationship with growth and development indicators (Mendoza et al., 2014). For example, Bayraktar (2013) considers the link between FDI and business simplicity indicators as one potential source of FDI change in the period from 2004 to 2010. The results show that countries with better business outcomes attract more FDIs. 
When considering developing countries, improvements in the „ease of doing business“ indicators can have a partial impact on determining higher FDI flows in these countries. This study also shows that there is a steady increase in the share of FDI flows in developing countries while falling in developed countries. In addition, the difference in the growth rate of developed and developing countries is a factor that can explain the change in FDI flows from developed countries to developing countries. The results further show that Doing Business indicators are almost unchanged in developed countries, while rapidly change their values in developing countries. There are significant improvements in starting a business, closing down businesses and protecting investors. Piwon \& Ramírez (2010) considered whether the business indicators affected the FDI, and indicate that there is a positive link between the government's actions to increase FDI flows. Using the regression model, it is concluded that increasing the Doing Business rank by one place contributes to an increase in investments of over $\$ 44$ million. Similar research indicates that starting a business, registering assets, obtaining loans, working on building permits, protecting investors, crossing borders and executing contracts are indicators that are directly and significantly related to FDI in Asian economies (Shahadan et al., 2014). The survey also showed that the closure of businesses or the resolution of insolvency are not desirable for total net FDI, but also that they do not have a significant impact on their attractiveness. On the one hand, net FDIs are in a positive correlation with the indicators of obtaining loans and investor protection, on the other hand, they have a slight negative correlation with indicators related to closing a business or resolving insolvency. A positive and significant effect on the flow of FDI has an indicator of asset registration, bearing in mind that ownership rights are the essence of providing investment, productivity and growth. The results of the analysis suggest that property owners who are registered can invest more easily, as well as having a greater chance of getting a loan when they use the property as a basis for a mortgage.

\section{EASE OF DOING BUSINESS AND ITS IMPACT ON FDI INFLOWS}

In order to improve the attractiveness of the developing country for FDI, an assessment of the importance of openness, infrastructure availability and sound economic and political conditions was carried out (Sekkat et al., 2007). Based on the results of the research, it was concluded that these factors are particularly significant in South Asia, Africa and the Middle East, and that the impact of these factors is higher on FDI in the manufacturing sector in relation to total FDI. In addition, the impact of infrastructure on FDI was examined and pointed to the significant positive impact of infrastructure, in the short and long term, on FDI inflows (Rehman et al., 2011). The results showed that in the short term, $1 \%$ increase of the infrastructure influences the increase of the FDI by $1.03 \%$, while in the long run, the same percentage of infrastructure increase contributes to the increase of the FDI inflows by $1.31 \%$. The survey also shows that the size of the market has a positive relationship, and the course has a significant negative impact on the infrastructure, in the short and long term. Better Doing Business ranking contributes to the higher FDI inflows, and it suggests that there is a more attractive investment climate in a country. FDI inflows are higher in countries with better Doing Business indicators, and economies that provide a good regulatory environment for domestic companies seek to provide the same for foreign companies. 
Therefore, Doing Business set of indicators can be treated as the international instrument for changing behaviours, not only for the purpose of motivating national investors, but also for attracting foreign investors. The fact is that the attraction does not have to be linked to a high level of FDI. Doing Business indicators are compared with other known data on FDI inflows related to functioning of foreign business entities under the direct control of the government. The way that Doing Business indicators affect FDI is analyzed if the country's change in FDI inflow level is compared to Doing Business indicators' values for that year. Fostering FDI inflows is also affected by macroeconomic factors such as human capital, high per capita income, which cannot be influenced by the government. The working framework includes desirable legislation, an open business culture for foreigners, and valuable national institutions. The main indicators of FDI are: the size of the market, the growth of the market and the level of education of the domestic workforce, whereby the appropriate working framework for FDI is not sufficient for investment attraction. In order to enable the FDI inflow, it is necessary that the country has a certain positive location and good institutions.

The research identifies two groups of descriptive factors in terms of FDI inflows: gravity factors (legislation, closeness, market size) and factor endowments (labour force, capital) (Shahadan et al., 2014). Most of the FDI inflows are explained by gravity factors, but policy and institutional environment are also significant. Companies are expected to invest in those countries where governments are less likely to control their operational tasks. This means free capital movement, lower corporate taxes, less corruption, and possibility to hold majority ownership in a local subsidy. If government defines a lot of legal procedures, there is an increase in costs for the enterprise, which finds a way to reduce FDI flows to that country. In addition to being an FDI source of external capital, they significantly contribute to economic growth and development. Key determinants of FDI are market-based: GDP per capita, gross domestic product, natural resources, production costs, level of corruption and infrastructure. In addition, a significant feature is the provision of the working framework, an economic system created by the government on a long-term basis, to allow foreign investment based on the attractiveness with respect to other countries. Based on the World Bank policy research, it is suggested that, while elements in certain determinants of Doing Business ranking are associated with increased FDI inflows, the ranking for an average country has a significant signalling effect for investors. In addition, it has not been shown that a significant improvement in the Doing Business ranking (or "country reform") influences a higher inflow of FDI, given that in developing countries, the relationship is not significant (World Bank, 2011).

A survey of six Asian countries (Afghanistan, Pakistan, Iran, India, Sri Lanka and Bangladesh) considered the index of business simplicity as part of the working framework for describing FDI inflows (Shahadan et al., 2014). The link between the Doing Business indicators for the net FDI inflow in the period 2004-2013 was considered. Indicators aim to point to the level of quality of institutions in a country. The results of the survey demonstrate the importance of the link between the Doing Business indicators and the FDI inflow, and that Doing Business indicators reflect a general investment climate that is significant only for small and medium-sized domestic enterprises. The research also indicates that there is a direct link between FDI and actions taken by the government.

The impact of institutional performances on FDI is not easy to measure. Institutional factor is significant, especially for developing economies, where weak institutions create poor 
infrastructure, which leads to a fall in profitability, and consequently to a decrease in FDI. The degree of institutional development is the essence of attracting FDI, based on a reduction in transaction costs of establishing local operations (Bevan \& Estrin, 2004). The authors point out that countries with better developed institutions in the market economy have a higher FDI inflow, as well as countries with more advanced private sector development and greater privatization. The results also show that countries with more developed and more effective legal systems also have a higher inflow of FDI, and there is some evidence that the liberalization of domestic and international markets has a significant positive impact on FDI inflows. The importance of the quality of institutions is indisputable for multinational corporations, that is, the good quality of institutions creates a friendly environment and this is the main factor for attracting FDI. Wei (2000) concludes that there are three main factors in the quality of institutions, both regulatory and legal systems and legislation. They are key determinants of attracting FDI inflows, and have to be focused on attracting FDI inflows. The corruption factor has been identified as negative for the FDI inflow.

\section{RESEARCH Methodology AND HYPOTHESES}

In this paper, the key variables are FDI inflows and Doing Business indicators. The FDI dataset was used from the basis of the World Bank and measured using FDI inflows (in\% of GDP), and Doing Business indicators were determined on the basis of the World Bank's Doing Business reports. Data refer to the period 2010-2017 for the Republic of Serbia. Dependent variable is FDI inflows expressed in \% of GDP. Doing Business indicators are used for the purpose of research as independent variables. The index of Ease of Doing Business, as a composite index, is the non-weighted average of the value of each of these indicators. The value of this index ranges from 0 to 100 . Based on the index values, an appropriate rank is assigned to a given country on a global list.

The aim of the paper is to analyze the link between the Doing business indicators and the FDI inflows, and to define possible directions of improving the business environment in the Republic of Serbia. In accordance with the goal of the research, the following hypothesis is defined and tested:

H1: There is interdependence between the Ease of Doing Business index (and its components) and the FDI inflows.

In order to analyze the relationship between the Doing Business indicators and the FDI inflows, dynamic and correlation analysis will be applied. Dynamic analysis will look at the trend of indicators values in the period 2010-2017, while the correlation analysis will assess the interdependence of FDI inflow and the value of the Ease of Doing Business index. The correlation analysis is based on Spearman's correlation coefficient (a nonparametric indicator of variation between variables). The values of this coefficient range from -1 to +1 , with a coefficient greater than zero, indicating a direct or positive correlation between the variables, and a value less than zero on an inverse or negative relationship between the variables. A stronger correlation between the variables is achieved if the correlation coefficient is absolutely closer to 1 , while the linear connection is weaker if the value is closer to zero. 


\section{RESEARCH RESULTS AND DISCUSSION}

In relation to the aforementioned methodology and defined research hypotheses, the following variables will be included in the analysis:

FDI - Foreign direct investment, in percentage of GDP

EDB- Ease of doing business, indicator score

X1 - Starting a Business, indicator score

X2 - Dealing with Construction Permits, indicator score

X3 - Getting electricity, indicator score

X4 - Registering property, indicator score

X5 - Getting credit, indicator score

X6 - Protecting minority investors

X7 - Paying taxes, indicator score

X8 - Trading across borders, indicator score

X9 - Enforcing contracts, indicator score

X10 - Resolving insolvency, indicator score

In order to get data for the entire observed period, harmonization of methodologies was performed. Table 1 shows the scores of indicators used in the analysis. The Protecting Minority Investors indicator is excluded from further analysis, because it does not show changes in scores during the observed period.

Table 1 Scores of indicators

\begin{tabular}{|c|c|c|c|c|c|c|c|c|c|c|c|c|}
\hline & FDI & $\begin{array}{l}\text { Ease of doing } \\
\text { business }\end{array}$ & $\mathrm{X} 1$ & $\mathrm{X} 2$ & $\mathrm{X} 3$ & $\mathrm{X} 4$ & $\mathrm{X} 5$ & X6 & $\mathrm{X} 7$ & $\mathrm{X} 8$ & X9 & X10 \\
\hline 2010 & 4.291 & 57.57 & 87.15 & 19.27 & 75.63 & 62.26 & 75.00 & 46.67 & 53.38 & 69.5 & 59.51 & 27.35 \\
\hline 2011 & 10.61 & 58.30 & 86.67 & 19.27 & 75.74 & 65.65 & 75.00 & 46.67 & 52.43 & 70.26 & 59.51 & 31.77 \\
\hline 2012 & 3.132 & 59.60 & 86.69 & 19.27 & 75.86 & 78.36 & 81.25 & 46.67 & 52.43 & 70.52 & 58.61 & 26.31 \\
\hline 2013 & 4.525 & 60.55 & 88.80 & 20.80 & 76.00 & 78.38 & 81.25 & 46.67 & 52.43 & 71.24 & 58.61 & 31.36 \\
\hline 2014 & 4.523 & 60.57 & 88.86 & 20.80 & 75.99 & 78.36 & 81.25 & 46.67 & 52.44 & 72.48 & 57.59 & 31.24 \\
\hline 2015 & 6.311 & 59.77 & 89.03 & 21.19 & 76.20 & 71.64 & 81.25 & 46.67 & 50.36 & 72.13 & 57.59 & 31.29 \\
\hline 2016 & 6.148 & 62.20 & 89.06 & 30.49 & 72.39 & 71.96 & 81.25 & 46.67 & 63.33 & 72.13 & 57.59 & 31.62 \\
\hline 2017 & 6.948 & 65.33 & 91.80 & 45.86 & 69.93 & 76.63 & 81.25 & 46.67 & 67.35 & 72.13 & 55.29 & 32.24 \\
\hline
\end{tabular}

Table 2 Relative changes of indicators

\begin{tabular}{lrrrrrrrrr}
\hline Year & X1 & X2 & \multicolumn{1}{c}{ X3 } & \multicolumn{1}{c}{ X4 } & X5 & \multicolumn{1}{c}{ X7 } & X8 & X9 & \multicolumn{1}{c}{ X10 } \\
\hline 2011 & $-0.55 \%$ & $0.00 \%$ & $0.15 \%$ & $5.44 \%$ & $0.00 \%$ & $-1.78 \%$ & $1.09 \%$ & $0.00 \%$ & $16.16 \%$ \\
2012 & $0.02 \%$ & $0.00 \%$ & $0.16 \%$ & $19.36 \%$ & $8.33 \%$ & $0.00 \%$ & $0.37 \%$ & $-1.51 \%$ & $-17.19 \%$ \\
2013 & $2.43 \%$ & $7.94 \%$ & $0.18 \%$ & $0.03 \%$ & $0.00 \%$ & $0.00 \%$ & $1.02 \%$ & $0.00 \%$ & $19.19 \%$ \\
2014 & $0.07 \%$ & $0.00 \%$ & $-0.01 \%$ & $-0.03 \%$ & $0.00 \%$ & $0.02 \%$ & $1.74 \%$ & $-1.74 \%$ & $-0.38 \%$ \\
2015 & $0.19 \%$ & $1.88 \%$ & $0.28 \%$ & $-8.58 \%$ & $0.00 \%$ & $-3.97 \%$ & $-0.48 \%$ & $0.00 \%$ & $0.16 \%$ \\
2016 & $0.03 \%$ & $43.89 \%$ & $-5.00 \%$ & $0.45 \%$ & $0.00 \%$ & $25.75 \%$ & $0.00 \%$ & $0.00 \%$ & $1.05 \%$ \\
2017 & $3.08 \%$ & $50.41 \%$ & $-3.40 \%$ & $6.49 \%$ & $0.00 \%$ & $6.35 \%$ & $0.00 \%$ & $-3.99 \%$ & $1.96 \%$ \\
\hline Average & $0.75 \%$ & $14.87 \%$ & $-1.09 \%$ & $3.31 \%$ & $1.19 \%$ & $3.77 \%$ & $0.53 \%$ & $-1.03 \%$ & $2.99 \%$ \\
$2017 / 2010$ & $5.34 \%$ & $137.99 \%$ & $-7.54 \%$ & $23.08 \%$ & $8.33 \%$ & $26.17 \%$ & $3.78 \%$ & $-7.09 \%$ & $17.88 \%$ \\
\hline
\end{tabular}


The Construction Permits indicator shows the highest average annual change. The value of this indicator increases by an average of $14.87 \%$ in the observed period, although in the three observed years there were no changes regarding this indicator. The score of this indicator increased by $137.99 \%$ in 2017 compared to 2010 . The only indicators that have recorded a decline in scores (by about 7\%) are Getting Electricity and Enforcing Contract.

Table 3 Relative changes of FDI and Ease of Doing Business 2010-2017

\begin{tabular}{lcc}
\hline & $\begin{array}{c}\text { Relative change of } \\
\text { FDI }\end{array}$ & $\begin{array}{c}\text { Relative change of } \\
\text { Ease of Doing } \\
\text { Business }\end{array}$ \\
\hline 2010 & $147.26 \%$ & $1.27 \%$ \\
2011 & $-70.48 \%$ & $2.23 \%$ \\
2012 & $44.48 \%$ & $1.59 \%$ \\
2013 & $-0.04 \%$ & $0.03 \%$ \\
2014 & $39.53 \%$ & $-1.33 \%$ \\
2015 & $-2.58 \%$ & $4.08 \%$ \\
2016 & $13.01 \%$ & $5.03 \%$ \\
2017 & $24.45 \%$ & $1.84 \%$ \\
Average & $61.92 \%$ & $13.48 \%$ \\
Relative change 2017/2010 & Source: Author's calculation
\end{tabular}

Source: Author's calculation

During the observed period, the FDI inflows increased by $24.45 \%$ annually, and the FDI inflow in 2017 is $61.92 \%$ higher compared to 2010. The Ease of Doing Business indicator had much lower intensity dynamics, the average annual change amounted to $1.84 \%$, while the score of this indicator in the latest year in relation to the first year increased by $13.48 \%$.

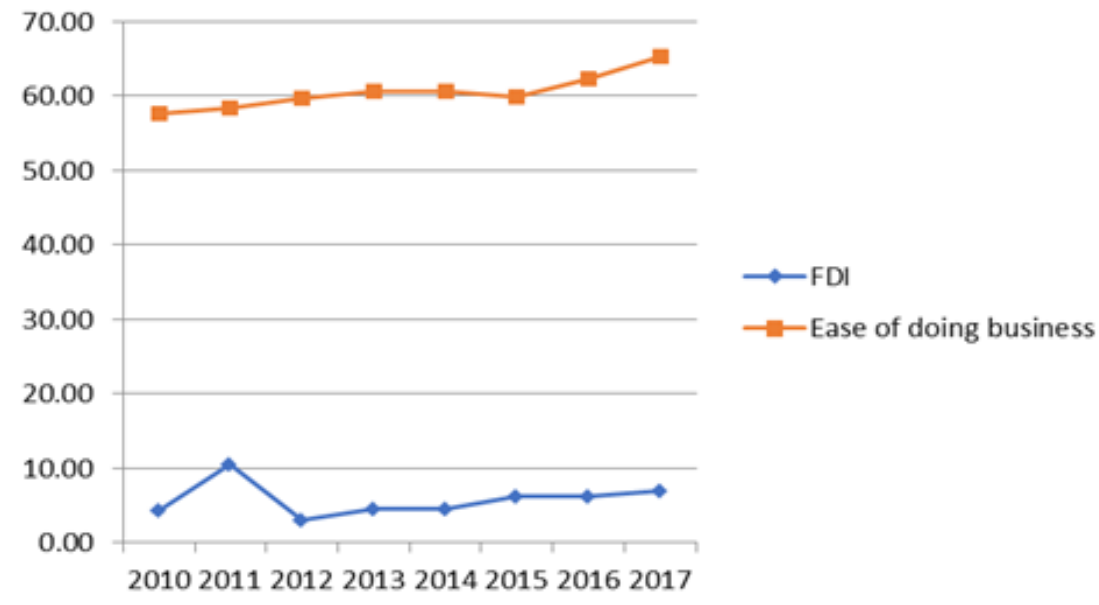

Fig. 1 Graphical presentation of the changes of indicators during the observed period Source: Author's presentation 
The dynamics of FDI is characterized by higher oscillations during the analyzed period. Both observed phenomena, FDI inflows and Ease of Doing Business indicators, are characterized by a positive tendency in the period beyond 2015 .

Table 4 presents calculated values of Spearman's correlation coefficients. The Spirman's correlation coefficient is a non-parametric indicator of the variation between two variables. It's values range from -1 to +1 , with coefficient values greater than zero, indicating a positive relationship between variables, while values less than zero refer to the existence of a negative relationship between the observed variables. Based on the values of the Spearman's rho coefficients in Table 4, it can be noted that there is a strong correlation between the Resolving insolvency indicator and FDI (0.905). In addition, there is a direct interdependence between FDI and the indicators Dealing with Construction Permits (0.454), Starting a Business (0.286), Trading across borders (0.171) and Paying taxes (0.024). Coefficient values less than zero indicate negative correlation between foreign direct investment and Registering property (-0.311), Getting credit (-0.126), Getting electricity (-0.19), as well as Enforcing contracts $(-0.259)$ indicators.

Table 4 Matrix of correlation coefficients

\begin{tabular}{|c|c|c|c|c|c|c|c|c|c|c|c|c|}
\hline & Coefficients & FDI & EDB & $\mathrm{X} 1$ & $\mathrm{X} 2$ & $\mathrm{X} 3$ & $\mathrm{X} 4$ & $\mathrm{X} 5$ & $\mathrm{X} 7$ & $\mathrm{X} 8$ & $\mathrm{X} 9$ & $\mathrm{X} 10$ \\
\hline \multirow[t]{2}{*}{ FDI } & $r_{s}$ & 1.000 & .286 & .286 & .454 & -.190 & -.311 & -.126 & .024 & .171 & -.259 & $.905^{* *}$ \\
\hline & Sig. (2-tailed) & & .493 & .493 & .258 & .651 & .453 & .766 & .954 & .686 & .535 & .002 \\
\hline \multirow[t]{2}{*}{ EDB } & $r_{s}$ & & 1.000 & $.857^{* *}$ & $.896^{* *}$ & -.262 & .515 & $.756^{*}$ & .512 & $.830^{*}$ & $-.902^{* *}$ & .524 \\
\hline & Sig. (2-tailed) & & & .007 & .003 & .531 & .192 & .030 & .194 & .011 & .002 & .183 \\
\hline \multirow[t]{2}{*}{$\mathrm{X} 1$} & $r_{s}$ & & & 1.000 & $.970^{* *}$ & -.262 & .156 & .630 & .512 & $.756^{*}$ & $-.914^{* *}$ & .429 \\
\hline & Sig. (2-tailed) & & & . & .000 & .531 & .713 & .094 & .194 & .030 & .001 & .289 \\
\hline \multirow[t]{2}{*}{$\mathrm{X} 2$} & $r_{s}$ & & & & 1.000 & -.233 & .204 & .650 & .428 & $.755^{*}$ & $-.911^{* *}$ & .589 \\
\hline & Sig. (2-tailed) & & & & & .578 & .628 & .081 & .291 & .030 & .002 & .124 \\
\hline \multirow[t]{2}{*}{$\mathrm{X} 3$} & $r_{s}$ & & & & & 1.000 & .323 & .252 & $-.878^{* *}$ & .146 & .136 & -.429 \\
\hline & Sig. (2-tailed) & & & & & & .435 & .547 & .004 & .729 & .748 & .289 \\
\hline \multirow[t]{2}{*}{$\mathrm{X} 4$} & $r_{s}$ & & & & & & 1.000 & $.760^{*}$ & -.074 & .454 & -.354 & -.096 \\
\hline & Sig. (2-tailed) & & & & & & & .028 & .862 & .258 & .389 & .821 \\
\hline \multirow[t]{2}{*}{$\mathrm{X} 5$} & $r_{s}$ & & & & & & & 1.000 & .000 & $.775^{*}$ & $-.784^{*}$ & .000 \\
\hline & Sig. (2-tailed) & & & & & & & & 1.000 & .024 & .021 & 1.000 \\
\hline \multirow[t]{2}{*}{$\mathrm{X} 7$} & $r_{s}$ & & & & & & & & 1.000 & .175 & -.367 & .342 \\
\hline & Sig. (2-tailed) & & & & & & & & . & .679 & .371 & .408 \\
\hline \multirow[t]{2}{*}{ X8 } & $r_{s}$ & & & & & & & & & 1.000 & $-.886^{* *}$ & .220 \\
\hline & Sig. (2-tailed) & & & & & & & & & & .003 & .601 \\
\hline \multirow[t]{2}{*}{ X9 } & $r_{s}$ & & & & & & & & & & 1.000 & -.358 \\
\hline & Sig. (2-tailed) & & & & & & & & & & & .384 \\
\hline \multirow[t]{2}{*}{$\mathrm{X} 10$} & $r_{s}$ & & & & & & & & & & & 1.000 \\
\hline & Sig. (2-tailed) & & & & & & & & & & & \\
\hline
\end{tabular}

Source: Author's calculation 
Table 5 Correlation coefficients between FDI and all other indicators

\begin{tabular}{lcc}
\hline Indicator & Correlation Coefficient & Sig. (2-tailed) \\
\hline Ease of doing business & 0.286 & 0.493 \\
Starting a business & 0.286 & 0.493 \\
Dealing with construction permits & 0.454 & 0.258 \\
Getting electricity & -0.19 & 0.651 \\
Registering property & -0.311 & 0.453 \\
Getting credit & -0.126 & 0.766 \\
Paying taxes & 0.024 & 0.954 \\
Trading across borders & 0.171 & 0.686 \\
Enforcing contracts & -0.259 & 0.535 \\
Resolving insolvency & $.905^{* *}$ & 0.002 \\
\hline
\end{tabular}

Source: Author's calculation

The highest level of agreement with FDI is indicated by the indicator Resolving insolvency (0.905), with a significance level of 0.002 , which indicates that this agreement is statistically significant. Further, there is a compliance between the FDI inflows and the Construction Permits indicator (0.454). FDI inflows are indirectly correlated with the indicators: Getting Electricity (-0.19), Registering Property (-0.311), Getting Credit (0.126), and Enforcing contracts (-0.259). For the Getting electricity and Enforcing contracts, indicators are clear as their score decreases during the observed period. The score of the Getting credit indicator is slightly constant, so this value is obtained (there are no oscillations in the movement), so it is almost impossible to determine the relationship.

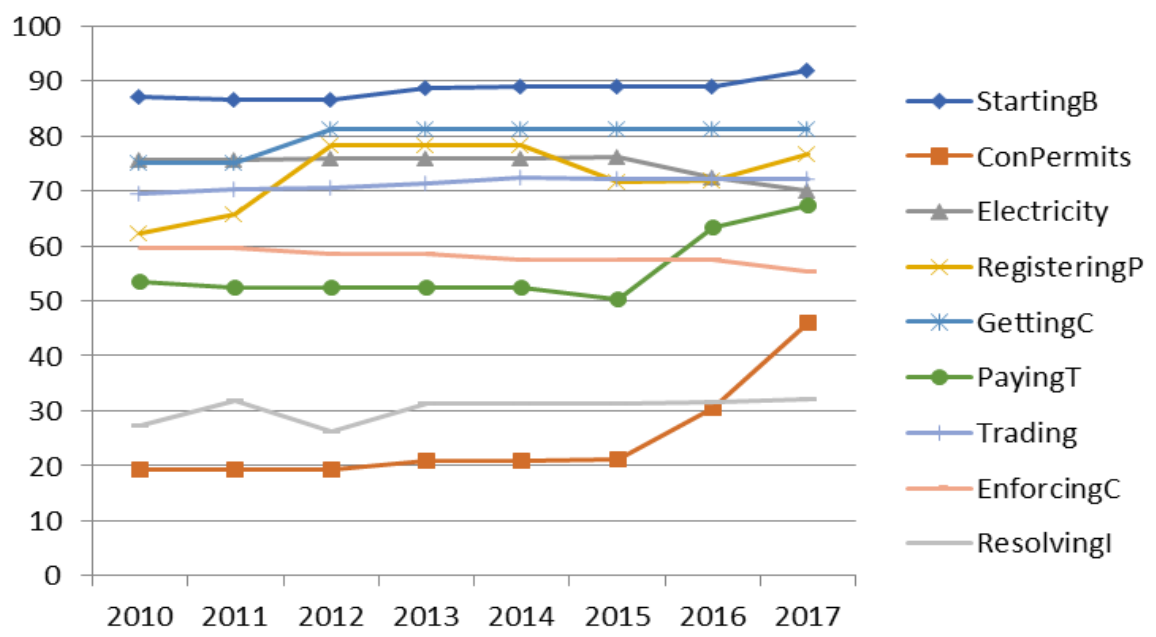

Fig. 2 Graphical presentation of indicator changes Source: Author's presentation 


\section{CONCLUSION}

The paper examines the interdependence of the indicators of Starting Business, Construction Permits, Getting electricity, Registering property, Getting credit, Paying taxes, Trading across, Enforcing contracts, Resolving insolvency and the FDI inflows (in percentage of GDP) in the Republic of Serbia during the period 2010-2017.

During the observed period, the highest level of agreement with FDI is indicated by the indicator Resolving insolvency (correlation coefficient is 0.905), while the following indicators have a statistically significant correlation with the FDI inflows: Construction Permits, Starting Business, Paying taxes, and Trading across borders. FDI inflows are negatively correlated with the indicators Getting Electricity, Registering Property, Getting Credit, and Enforcing contracts (-0.19, $-0.311,-0.126$, and -0.259 , respectively).

The results of the survey indicate that the Resolving insolvency and Construction Permits indicators occupy a particularly important place among the Ease of Doing Business indicators, which indicates that there is a direct link between the FDI inflows and the quality of the regulations defined by Doing Business indicators. This can serve as a basis for government activities towards improving the quality of the business environment in order to attract as many FDI projects as possible.

\section{REFERENCES}

Bayraktar, N. (2013). Foreign Direct investment and Investment Climate, WEI International Academic Conference Proceedings Istanbul, Turkey.

Besley, T. \& Ghatak, M. (2009). Property Rights and Economic Development. In Rodrik, D. \& Rosenzweig, M. (eds.) Handbook of Development Economics Vol. 5. The Netherlands: North-Holland Elsevier BV.

Bevan, A., Estrin, S. \& Meyer, K.E. (2004). Institution building and the integration of Eastern Europe in international production. International Business Review, 13, (1), 43-64.

Bird, R.M. (1989). Tax Administrative Dimension of Tax Reform in Developing Countries. In M. Gillis, (ed.) Tax Reform in Developing Countries Durham, NC: Duke University Press.

Bobenič Hintošová, A., Zuzana Kubíková, Z. \& Ručinský, R. (2016). Does quality of business environment influence foreign direct investment inflows? A case of Central European countries. Central European Journal of Management, 3, (1), 5-13.

Bose, N., Murshid, A.P. \& Wurm, M.A. (2012). The Growth Effects of Property Rights: The Role of Finance. World Development, 40 (9), 1784-1797.

Dabla-Norris, E., Gradstein, M. \& Inchauste, G. (2008). What Causes Firms to Hide Output? The Determinants of Informality. Journal of Development Economics, 85 (1), 1-27.

Dixit, A. (2009). Governance Institutions and Economic Activity. The American Economic Review, 99 (1), 3-24.

Djankov, S., Glaeser, E.L., La Porta, R., Lopez de Silanes, F. \& Shleifer, A. (2003). The New Comparative Economics. NBER Working Paper Series 9608.

King, R.G. \& Levine, R. (1993). Finance and Growth: Schumpeter Might be Right. The Quarterly Journal of Economics, 108 (3), 717-737.

Klapper, L., Laeven, L. \& R. Rajan. (2006). Entry regulation as a barrier to entrepreneurship. Journal of Financial Economics, 82, 591-629.

Lucas, R. (1988). On the Mechanics of Economic Development. Journal of Monetary Economic, 22, 3-42.

Mendoza, R.U., Canare, T.A. \& Ang, A.P. (2014). Doing Business: A Review of Literature and its Role in APEC 2015. PIDS Discussion Paper Series, No. 2015-37, Philippine Institute for Development Studies (PIDS), Philippines, 1-46.

MogesEbero, E. \& Begum, M. (2016). The desirability of Doing Business and Flow of Foreign Direct Investment nexus: The Case of Ethiopia. International Research Journal of Engineering and Technology (IRJET), 03 (05), 2049-2057.

Moscoso Boedo, H.J. \& Mukoyama, T. (2012). Evaluating the Effects of Entry Regulations and Firing Costs on International Income Differences. Journal of Economic Growth, 17 (2), 143-170. 
North, D. \& Thomas, R.P. (1973). The Rise of the Western World: A New Economic History. Cambridge, UK: Cambridge University Press.

Piwonski, K. \& Ramírez, A. (2010). Does the 'Ease of Doing Business' In a Country Influence its Foreign Direct Investment Inflows? Senior Capstone Project.

Quintin, E. (2008). Limited Enforcement and the Organization of Production. Journal of Macroeconomics, 30 (3), 1222-1245.

Rehman, C., Ilyas, M., MobeenAlam, H. \& Akram, M. (2011). The Impact of Infrastructure on Foreign Direct Investment: The Case of Pakistan. IJBM, 6 (5).

Schumpeter, J. (1912). Theorie der Wirtschaftlichen Entwicklung. Leipzig: Dunker \& Humblot. [The Theory of Economic Development, 1912, translated by R. Opie. Cambridge, MA: Harvard University Press, 1934.]

Sekkat, K. \& Veganzones-Varoudakis, M.A. (2007). Openness, investment climate, and FDI in developing countries. Review of Development Economics, 11 (4), 607-620.

Shahadan, F., Sarmidi, T. \& Jan Faizi, F. (2014). Relationships between Doing Business Indexes and FDI Net Inflows: Empirical Evidence from Six Asian Countries (Afghanistan, Bangladesh, India, Iran, Pakistan and Sri Lanka). Persidangan Kebangsaan Ekonomi Malaysia ke-9 (PERKEM ke-9), 609 - 625.

Wei, S. (2000). How taxing is corruption on international investors? Rev. Econ. Stat., 82 (1), 1-11.

World Bank and Doing Business. (2011). Doing Business 2012: Doing business in a more transparent world.

World Bank. (2013). Doing Business 2014: Understanding Regulations for Small and Medium-Size Enterprises. Washington: The World Bank.

World Bank, https://www.worldbank.org/, Accessed on: 25.12.2018.

\section{VEZA IZMEĐU INDIKATORA LAKOĆE POSLOVANJA I PRILIVA STRANIH DIREKTNIH INVESTICIJA U REPUBLICI SRBIJI}

Značaj indikatora lakoće poslovanja kao determinante FDI priliva je privukao pažnju u utvrđivanju njihovih veza. Cilj istraživanja je da se ispita veza između indikatora lakoće poslovanja $i$ priliva stranih direktnih investicija (SDI). Dinamička $i$ korelaciona analiza su primenjene $u$ sagledavanju međuzavisnosti indikatora lakoće poslovanja: Pokretanje poslovanja, Izdavanje građevinskih dozvola, Uvođenje električne energije, Registrovanje imovine, Dobijanje kredita, Plaćanje poreza, Prekogranična trgovina, Sprovođenje ugovora, Rešavanje nesolventnosti i priliva SDI. Dobijeni rezultati pokazuju da indikatori Rešavanje nesolventnosti i Izdavanje građevinskih dozvola imaju najveći stepen slaganja sa SDI, dok negativno slaganje sa kretanjem SDI pokazuju indikatori Uvođenje električne energije, Registrovanje imovine, Dobijanje kredita i Sprovođenje ugovora. Glavni rezultati ovog istraživanja su korisni kreatorima ekonomske politike jer pružaju dobru osnovu za formulisanje strategije unapređenja poslovnog ambijenta u Republici Srbiji.

Ključne reči: SDI priliv, indikatori lakoće poslovanja, Republika Srbija 